\title{
The Impact of Person- Organization Fit on Job satisfaction and Turnover Intention An Applied Study on 6 October University
}

\begin{abstract}
The present study explores the relationships between person-organization fit, job satisfaction and turnover intention empirically in the private higher education sector in Egypt, based on a survey of academic staff of October University. It has been realized that all dimensions of person -organization fit (Value congruence. Goal congruence) have positively relation with job satisfaction and negatively relation with turnover intention. Moreover, job satisfaction mediates the relationship between person organization fit and turnover intention.Finally, the survey findings suggest that; It is certain that job satisfaction will mediate the relationship between the person-organization fit and turnover intention. The person-organization fit (in terms of value and goal congruence) will provide greater importance, which will then lead individuals to a higher level of employee job satisfaction. In the long run, individuals with a higher level of job satisfaction would be less likely to leave the organization .finally It is necessary for organizations to consider the relationship between (P-O) fit, job satisfaction and turnover intention in the formulation, Developing and maintaining of their retention strategies.
\end{abstract}

Key words: person organization fit, job satisfaction and turnover intention 


\section{Introduction:}

The utmost powerful and fundamental resource of any given organization is its employees. They are what make or break the long term competitiveness of the organization (Huselid, Jackson, \& Schuler, 1997).On the long run, what make a certain organization more or less powerful from the next is the power, commitment, and loyalty of its staff and employees. Pragmatic evidence indicates that organizations that successfully retain their top talent will thrive an overall greater percentage and for a longer period of time than its competitor (Holtom, MitchellatLee, \& Inderrieden, 2005). It is certainly agreed upon that one of the biggest challenges of an organization is the ability and skill to preserve their valuable staff (Boswell, Ren, \& Hinrichs, 2008).

Employee turnover become highly problematic as it calls for a significant amount of an organizations resources to recruit, interview and train new employees ( Mobley, 1982). Moreover, lower morale of the remaining employees is an added consequence of high turnover rates (Rainey, 2003), as well as loss of organizational memory (Huber, 1991), and low productivity (Johnson, 1995). It is of high importance for organizations to understand and comprehend the significance and effect of turnover and its consequential effect on its overall success and wellbeing. Thus it is essential to identify the turnover intention of employees in order to decrease the long term turnover rates. One of the key factors that can cause employees to leave a certain organization is how well they fit in the organizations environment. Favorable attitudes-experience, greater well-being and perform better (Hoffman \&Woehr, 2006; Kristof-Brown, Zimmerman,\&Johnson, 2005).

The person-organization (P-O) fit has been seen as a predictor of employee turnover (Arthur, Bell, Villado, \& Doverspike, 2006). Scholars in the field of 
human resource management and organizational behavior have shown great interest in the (P-O) fit due to its negative relationship with turnover intention (Cable \& DeRue, 2002; Hoffman \& Woehr, 2006; Schneider, 1987; Verquer, Beehr, \& Wagner, 2003) and several other individual and organizational level outcomes, such as organizational commitment, job satisfaction (Biswas\&Bhatnagar, 2013; Kim, Aryee, Loi, \& Kim, 2013; Resick, Baltes, \&Shantz, 2007) organizational citizenship behavior, organizational identification (Cable \&DeRue, 2002) and job performance (Kim et al., 2013).

A University future highly depends on the number, quality and effectiveness of its academic staff (Mwadiani, 2002). The sustainability and quality of any academic institution also depends on the quality, intellectual and creative abilities and commitments of its academic staff when compared to other organizations (Ng'ethe, Iravo, \& Namusonge, 2012). With respect to this issue that academic staffis fundamental and directorial factor in educating future generations, this researh seeks to examine the relationship between (P-O) fit with Staff members' turnover intention (TI) considering Job Satisfaction as a mediating variable in the higher education context in Egypt.

Based on the above argument and past literature, the present research makes a twofold contribution. First, it empirically investigates the relationship between Person-Organization (P-O) fit, and turnover intention while considering job satisfaction as a mediating variable. Second, as there is limited literature that shows the relationship between these variables in the context of Egypt. This study will help in adding knowledge to the existing body of literature by examining the impact of these variables in the private higher education sector. It will guide managers of the organizations to understand the phenomena of (P-O) fit that will help in engaging academic staff members in their jobs, so as to reduce their turnover intention. 


\subsection{Problem Research}

Higher education institutions depend on their employees' skills, knowledge and abilities for the effective delivery of services, and retaining talented employees has thus become a vital factor for these institutions (Naris\&Ukpere, 2010). It is thus necessary for organizations to consider the relationship between (P-O) fit, job satisfaction and turnover intention in the formulation of their retention strategies. The problem is derived from two main issues;

First, It is not clear from the literature how these three variables are interrelated in the Egyptian private higher educational context. Furthermore, there seems to be a paucity of research addressing (P-O) fit, job satisfaction and turnover intention in the private higher education context, Second, the number of academic staff of the 6 October University in Egypt has been gradually decreased from460 in 2015/2016 to 420 in 2016/2017, which represented as approximately $8 \%$ decrease, which means the From the abovementioned problem statement, the researcher found that there is a much less intention has been given to assess the mediating role of job satisfaction effects on the relationship between the (P-O) fit and turnover intention. The attempt of this research was to answer the following questions:

$\mathrm{Q}_{1}$ : What do Person-Organization (P-O) fit, Job Satisfaction (JS) and Turnover Intention (TI) mean? And what is their significance in the private higher education sector in Egypt?

$\mathrm{Q}_{2}$ : Is there a significant relationship between the person- organization (P-O) fit and Job Satisfaction (JS) in the private higher education sector in Egypt?

$\mathrm{Q}_{4}$ : Is there a significant relationship between the person-organization (P-O) fit and turnover intention in (TI) in the private higher education sector in Egypt? $\mathrm{Q}_{4}$ : Is Job Satisfaction plays a mediating role between person-organization (P-O) fit and turnover intention (TI)in the private higher education sector in Egypt? 


\subsection{Research objectives:}

The main objective of this research is to gain knowledge of employeeorganization relationship focusing on such variable of person-Organization (PO)fit and its relationship with Job Satisfaction and turnover intention; in such a framework, the present research aims to achieving the following objectives;

- Exploring the relationship between the person- organization (P-O) fit and Job Satisfaction in the private higher education sector in Egypt

- Exploring the relationship between the person- organization (P-O) fit and Turnover intention in the private higher education sector in Egypt

- Assessing the mediating role of Job Satisfaction (JS) in the relationship between the person- organization (P-O) and turnover intention (TI) in the private higher education sector in Egypt?

\section{Literature review}

\subsection{Person Organization Fit (P-O)}

Studies concerning the ( $\mathrm{P}-\mathrm{O})$ fit have indicated that the individual and organization "fit" increases the likelihood of the individual's willingness to stay with the organization. The term ( $\mathrm{P}-\mathrm{O})$ fit has been used to describe the congruence between individual and organizational goals; individual preferences or needs and organizational systems or structures; and individual personality and organizational climate (Parkes etal.,2001). (Kristof etal.,2005) defined (P-O) fit as the "compatibility between people and organizations that occurs when at least one entity provides what the other needs or they share similar fundamental characteristics or both" In other words, (P-O) fit that emphasizes the extent to which a person and the organization share similar characteristics (Sekiguchi, 2004). (P-O) fit is defined as the "congruency between patterns of organizational values and patterns of individual values"(Chatman,1989).(P-O) fit has often been conceptualized in terms of value congruence and goal congruence (Kristof-Brown, 1999). 
- Value congruence refers to the similarity of values of both the employee and the organization (Hoffman \&Woehr, 2006; Kristof-Brown, 1996). An individual, whose values are congruent with those of his organization, would generate a favorable attitude towards the organization (Arthur et al., 2006) and would have the tendency to remain in the organization (Kim etal.,2013; Schneider, 1987).

- Goal congruence refers to the extent of similarity between a person's own goals as compared to the goals of the organization (Verquer et al., 2003). A similarity of goals attracts individuals towards an organization whose goals are instrumental in meeting those of the individual.

There are many positive effects of high congruence between person and organization both for employees and organizations. A greater degree of (P-O) fit has been shown to be related to multiple organizational outcomes including enhanced organizational commitment, increased productivity, and reduced turnover (Van Vianen, 2000).

$\mathrm{H}_{1}$ : There is no statistically significant relationship between person-organization (P-O) fit (value congruence, goal congruence) and job satisfaction (JS) at private high institutes in Egypt.

\subsection{Turnover Intention}

Turnover intention is defined as the reflection of "the probability that an individual will change his or her job within a certain time period" (Sousa-Poza and Henneberger, 2002; Sousa- Poza, 2007). Also (Lacity, Lyer \& Rudramuniyaiah 2008) defined turnover intention as '... the extent to which an employee plans to leave the organization'. According to (Jaros,1997) turnover intention reflects the continuous and also general cognitive arousal toward leaving the organization. Reviewing literature of this subject indicates that turnover intention is a multi step process that consists of three components including mental, cognitive, and behavioral dimensions (Takase, 2001). 
The results of the different studies (Hendrix, Robbins, Miller \& Summers, 1998; Steensma, Van Breukelen \& Sturm, 2004) provide support for the high significance of turnover intention in investigating the individual's turnover behavior. Turnover intention captures the individual's perception and evaluation of job alternatives (Mobley et al., 1979). It has been argued by several scholars (Jaros et al., 1993;Muliawan et al., 2009; Tett \& Meyer, 1993) that turnover intention can be used as a valid proxy for actual labour turnover in general. Organizational studies suggested that intentions to leave are important for organizations and researchers because once people have actually implemented the behavior to quit; there is little likelihood of gaining access to them to understand their prior situation (Juhdi et al 2013). The causal relationship between turnover intention and actual turnover is well established in the management literature and the underlying premise is that behavior intent is a practical proxy of actual behavior (Maxwell et al., 2003)..

\subsection{Person-Organization (P-O) fit and Turnover intention (TI)}

A basic underlying assumption of the (P-O) fit literature is that people will be more attracted to and less likely to exit organizations where they find a close match (Elfenbein \& O'Reilly 2007, Schneider 1987). Previous studies have frequently proposed that a negative association between the $(\mathrm{P}-\mathrm{O})$ fit and turnover intention. Cable and Judge argued that Person organization fit may affect employees' intention of turnover (Cable \& Judge, 1996). As per as (Verquer etal., 2003), who conducted a meta-analysis of 21 studies, found that the (P-O) fit was negatively associated with the intention to quit. In addition, another meta-analysis of 121 studies (1967-2003) by (Hoffman and Woehr 2006) revealed that the (P-O) fit was related to turnover. A similar result was found in a study of deluxe hotels in Korea by (Jung \& Yoon, 2013). In general, these findings have consistently showed that individuals with a (P-O) fit tend to stay longer in an organization. 
$\mathrm{H}_{2}$ : There is no statistically significant relationship between person-organization (P-O) fit (value congruence, goal congruence) turnover intention (TI) at private higher institutes in Egypt.

\subsection{Mediating Role of job satisfaction}

Through extensive research it has been widely shown that job satisfaction acts as a mediating role between $\mathrm{P}-\mathrm{O}$ fit and turnover intention. A greater degree of P-0 fit has been shown to be related to multiple organizational outcomes including enhanced organizational commitment, increased productivity, and reduced turnover atthe manufacturing company in Yogyakarta and Surakarta (Van Vianen, 2000).

Further, it has been suggested that the relationship between P-O fit and turnover intention is mediated by the relationship between job satisfaction and organizational commitment (Westerman \& Cyr, 2004).Moreover it was found that Job satisfaction highly affects the decision of an employee to stay or leave the organization (Aydogdu\&Asikgil, 2011) as well been shown to relate closely to turnover intention (Chen \& Spector, 1991; Yucel, 2012).

Many studies have reported a significant negative relationship between job satisfaction and turnover intention (Price \& Mueller, 1981; Chan \& Morrison, 2000; Aryee, Watt, \& Min, 2001; Kohl and Goh, 1995; Shore \& Martin, 1989). Low job satisfaction effectively causes employees to look for another job and thus leaving the organization (Jaros, Jermier, Koehler, \&Sincich, 1993) Job satisfaction has been frequently used as a key predicator in the event of an employee or multiple employees exit the organization (De Moura, Abrams, Retter, Gunnarsdottir \& Ando, 2009).

Employee job satisfaction has been interconnected with how people think, feel and observe their jobs (Spector, 1997).It is widely used in the field of human resources, who thought that the internal and external features are elements of work 
satisfaction reports(Chang, 1999). In other words, job satisfaction, it is satisfying emotional state as a result of damage assessment of the occupation or the experience of a job. Organizational commitment is a predictor of various outcomes such as turnover and intention to leave the organization (Ferris \&Aranya, 1983), loyalty and level of effort given (Allen \& Meyer, 1996). Organizational commitment leads to important results three of which are decreased turnover, higher motivation, and high job satisfaction (O'Reilly \& Chatman, 1986). Vandenberghe and Tremblay (2008) suggested that organizational commitment is a mediator in the relationship between job satisfaction and turnover intention.

Previous studies also found that affective commitment mediates the relationship between job satisfaction and turnover intention (Netemeyer, Burton, \& Johnston, 1995. Cramer (1996) said that most model of turnover assumes that job satisfaction leads to greater organizational commitment. The main reason for this causal relationship seems that job satisfaction is an effective response to the work performed immediately after Job Satisfaction, Organizational Commitment, and Turnover Intention Joining the organization than any other aspect in working for the organization as objectives and values (Cramer, 1996).

According to fit theories, both the person and organizational environment can significantly affect an individual's behaviors and organizational outcomes (Chatman, 1991). In a recent study, (Biswas and Bhatnagar, 2013) examined the mediating role of Employee Engagement between P-O fit and organizational outcomes, such as job satisfaction and organizational commitment among employees in north-central India. The findings indicated that the $(\mathrm{P}-\mathrm{O})$ fit predicted job satisfaction and organizational commitment, which was mediated by Employee Engagement.

$\mathrm{H}_{3}$ : There is no statistically significant relationship between gob satisfaction (JS) and turnover intention (TI) at private higher institutes in Egypt 
$\mathrm{H}_{4}$ : Job satisfaction(JS) has a mediating effect on the relationship between Personorganization (P-O) fit and turnover intention at private higher institutes in Egypt .

\section{Research Model}

Person- Organization Fit (PO)

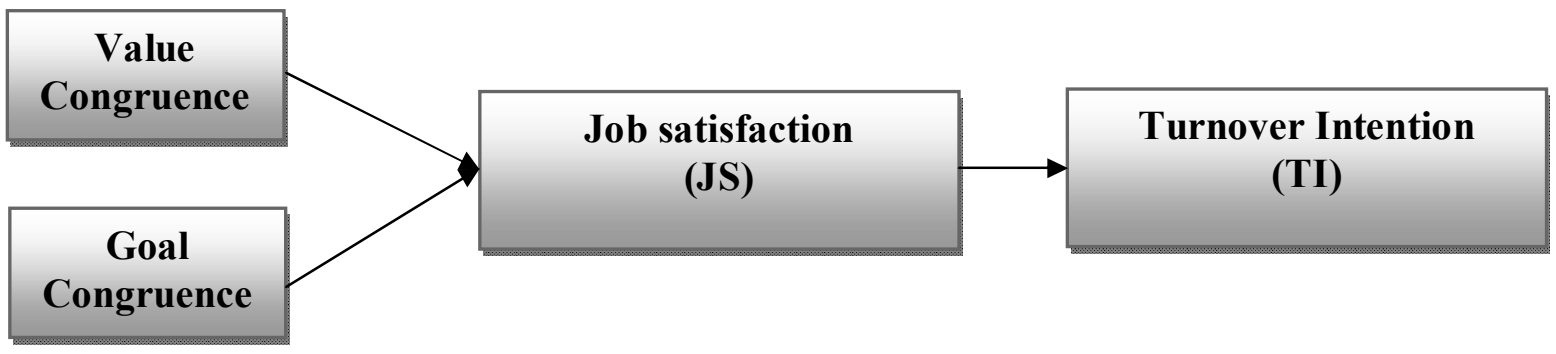

Source: Prepared by the researcher

\section{Research design and Methodology}

This present research aims at exploring the relationship between the Independent Variable person-Organization (P-O) fit and the Dependent Variable (Turnover Intention), and the extent to which the mediating variable (job satisfaction) mediates this relationship.

\subsection{Research Population:}

The present research population represents academic staff of October University which include $(\mathrm{N}=420)$ individuals.

The researcher adopted a complete census which include all the population size $(n=420)$ individuals in the study, 367vaild response out of 420.

\subsection{Research Variables Measurement:}

The main variables of the research are person-organization $(\mathrm{P}-\mathrm{O})$ fit, job satisfaction, and turnover intention. A survey research method will be used to collect data, using standard questions to measure these variables which are adopted from previous studies. 


\section{Person-Organization (P-O) Fit}

measures of Person-Organization (P-O) fit have been developed in terms of three item scales for measuring Value and Goal congruence, totaling six items (Cable \& DeRue, 2002; Vogel \& Feldman, 2009). These scales include items such as: "The things I value in life are very similar to the things my organization values" for measuring value congruence (Cable \&DeRue, 2002), and: "My Personal goals and the goals of my organization are very similar" for measuring goal congruence (Vogel \& Feldman, 2009).

\section{Turnover Intention (TI)}

Turnover Intention has been measured via three items scale used by (Roodt 2004), to assess employee's intent to leave. "I think a lot about leaving this organization";

"I am actively searching for an acceptable alternative to this organization"; "When I can, I will leave the organization.

\section{Job satisfaction (JS)}

Will be measured via five items scale used by ( Hackman and Oldham 1975) These scales include items such(i.e as my basic salary is sufficiently paid according to my daily working hours and work load ), i am satisfied with my chances for salary increases, the work $\mathrm{I}$ do is appreciated, $\mathrm{i}$ believe those that do well on the job have fair chances of being promoted, it is possible to get promoted fast in my job Five - Point likert Scale ranging from 1 "strongly disagrees" to 5 "strongly agree" will be used to give a degree for each statement for the three variables. The collected data will be analyzed using the statistical package SPSS

\subsection{Statistical Analysis and testing hypothesis}

In the following statistical techniques has been used to analyze the data collected and testing hypotheses.

\subsection{Reliability Analysis}

Was measured the reliability through the scale Cronbach's Alpha, the value of 
Alfa ranges between zero and one, if there is no stability in the data, the value of this parameter equal to zero, and on the contrary, if there is complete stability in the data, the value of this parameter equal to the one, and if this measure has equaled or increased from 0.60 , then it is possible to rely on the results of the study.

Table (1): The reliability measures on the sections of the questionnaire

\begin{tabular}{ccccc}
\hline Section & Description & \# of questions & $\begin{array}{c}\text { Alfa } \\
\text { Reliability } \\
\text { Coefficient }\end{array}$ & $\begin{array}{c}\text { Honesty } \\
{ }^{*} \text { Coefficient }\end{array}$ \\
\hline One & Values & 3 & 0.927 & 0.963 \\
Two & Goals & 3 & 0.617 & 0.785 \\
\hline Three & Job satisfaction & 5 & 0.854 & 0.924 \\
\hline Four & Turn over intention & 3 & 0.873 & 0.934 \\
\hline
\end{tabular}

(*) Honesty coefficient is the square root of reliability coefficient.

Based on table (1), it is clear that the value of Alfa is $(0.927,0.617,0.854,0.873)$ concerning the sections of the questionnaire respectively, which reflected on honesty coefficiency and its value was $(0.963,0.785,0.924,0.934)$ respectively. This means that the questionnaire is reliable and we can depend on the results obtained from this questionnaire.

\subsection{Descriptive Analysis}

We apply descriptive analysis to describe the variables of the questionnaire in terms of central tendency and dispersion, applying this to the sections of the study, the results are as following:

\section{Values congruence}

To determine the importance of "Values congruence" from the perspective of the sample, we conduct descriptive statistics (mean, relative mean, Standard deviation, coefficient of variation), and the results as follow: 
Table (2): The descriptive statistics concerning "Values congruence"

\begin{tabular}{|c|c|c|c|c|c|c|}
\hline Variables & Mean & $\begin{array}{c}\text { Relative } \\
\text { mean }\end{array}$ & $\begin{array}{c}\text { Std. } \\
\text { Deviation }\end{array}$ & C. $V^{(*)}$ & Agreement & Order \\
\hline Values congruence & 3.24 & 64.9 & 1.22 & 37.6 & Neutral & \\
\hline $\begin{array}{l}\text { Things that have value to me in life } \\
\text { are very similar to things that have } \\
\text { value to my organization }\end{array}$ & 3.40 & 68.0 & 1.44 & 42.2 & Agree & 1 \\
\hline $\begin{array}{l}\text { My personal values match the } \\
\text { values and culture of my } \\
\text { organization }\end{array}$ & 3.11 & 62.2 & 1.22 & 39.3 & Neutral & 3 \\
\hline $\begin{array}{l}\text { The values and culture of my } \\
\text { organization are suit with the things } \\
\text { that have value to me in life }\end{array}$ & 3.20 & 64.0 & 1.23 & 38.5 & Neutral & 2 \\
\hline
\end{tabular}

From the table we conclude that "Values congruence" (in general) is moderate from the perspective of the sample since the mean of responses is 3.24 which means that the degree of agreement is "Neutral", and the coefficient of variation is $37.6 \%$ which means that the degree of agreement is $62.4 \%$ which indicates that there is an agreement between the respondents.

Concerning the phrases, the degree of agreement is "Agree" concerning "Things that have value to me in life are very similar to things that have value to my organization", since the mean is 3.40 and "Neutral" concerning "The values and culture of my organization are suit with the things that have value to me in life", "My personal values match the values and culture of my organization" since the mean is $3.20,3.11$ respectively.

The importance of "Values" can be illustrated as shown in figure (2) as follows:

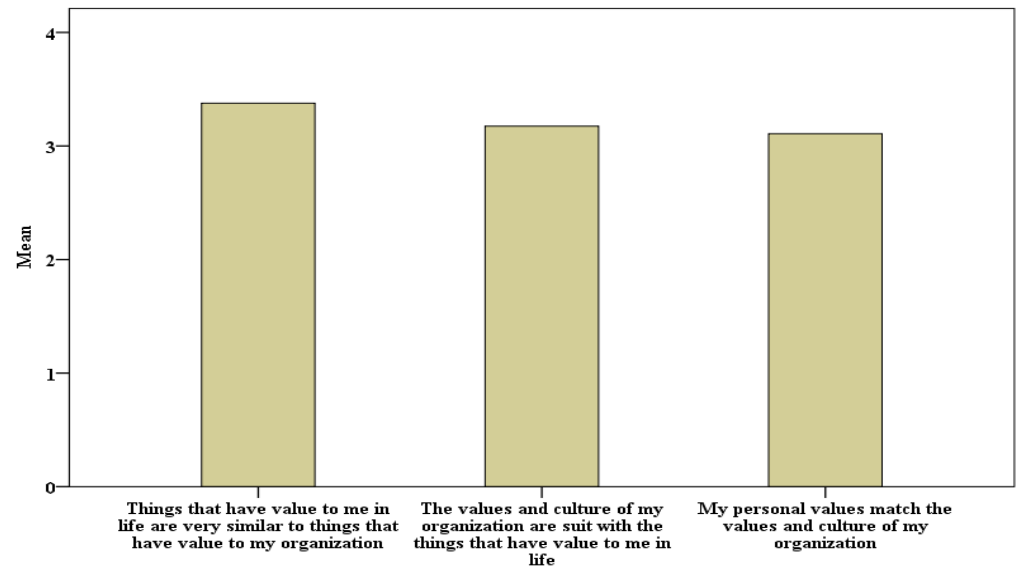

Figure (2): mean of sample responses concerning "Values congruence" 


\section{Goals congruence}

To determine the importance of "Goals" from the perspective of the sample, the descriptive statistics (mean, relative mean, Standard deviation, coefficient of variation), and the results provide the following:

Table( 3): The descriptive statistics concerning "Goals"

\begin{tabular}{lllllll}
\hline \multicolumn{1}{c}{ Variables } & Mean & $\begin{array}{c}\text { Relative } \\
\text { mean }\end{array}$ & $\begin{array}{c}\text { Std. } \\
\text { Deviation }\end{array}$ & C.V & Agreement & Order \\
\hline Goals congruence & 3.38 & 67.7 & 0.91 & 26.9 & Neutral & \\
\hline $\begin{array}{l}\text { I know the goals of my organization } \\
\text { My personal goals and the goals of my }\end{array}$ & 4.21 & 84.2 & 1.02 & 24.3 & $\begin{array}{l}\text { Strongly } \\
\text { agree }\end{array}$ & 1 \\
$\begin{array}{l}\text { organization are very similar } \\
\begin{array}{l}\text { I do not care about the goals of my } \\
\text { organization as much as my colleagues do }\end{array}\end{array}$ & 2.11 & 62.2 & 1.27 & 40.8 & Neutral & 2 \\
\hline
\end{tabular}

From the table we conclude that "Goals" (in general) is Moderate from the perspective of the sample since the mean of responses is 3.38 which means that the degree of agreement is "Neutral", and the coefficient of variation is $26.9 \%$ which means that the degree of agreement is $73.1 \%$ which indicates that there is an agreement between the respondents.

Concerning the phrases, the degree of agreement is "Strongly agree" concerning "I know the goals of my organization", since the mean is 4.21 and "Neutral" concerning "My personal goals and the goals of my organization are very similar", "I do not care about the goals of my organization as much as my colleagues do" since the mean is $3.11,2.83$ respectively.

The following figure shows the importance of "Goals congruence".

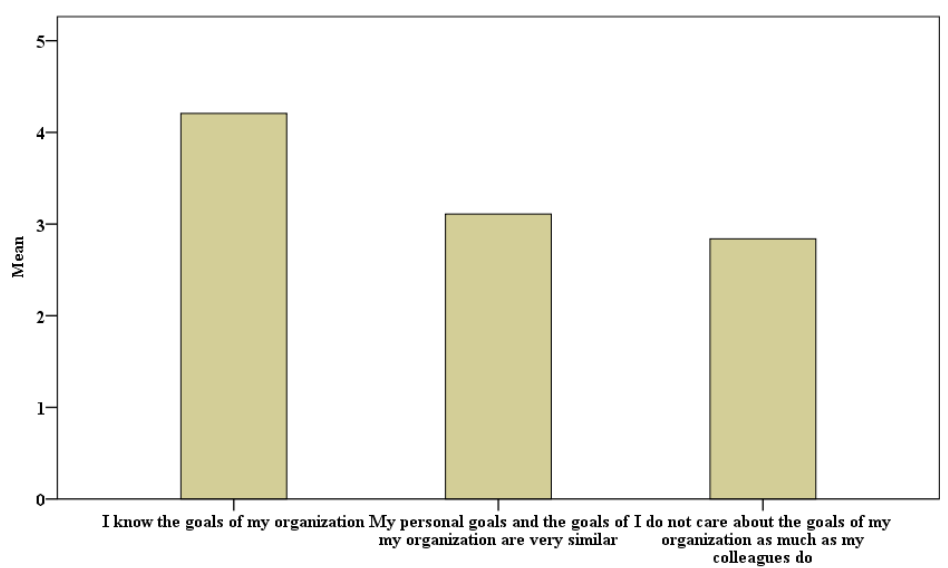

Figure (3): mean of sample responses concerning "Goals" 


\section{Job satisfaction}

To determine the importance of "Job satisfaction" from the perspective of the sample, we conduct descriptive statistics (mean, relative mean, Standard deviation, coefficient of variation), and the results as follow:

Table (4): The descriptive statistics concerning "Job satisfaction"

\begin{tabular}{|c|c|c|c|c|c|c|}
\hline Variables & Mean & $\begin{array}{c}\text { Relative } \\
\text { mean }\end{array}$ & $\begin{array}{c}\text { Std. } \\
\text { Deviation }\end{array}$ & C.V & Agreement & Order \\
\hline Job satisfaction & 3.23 & 64.6 & 1.03 & 32.0 & Neutral & \\
\hline $\begin{array}{l}\text { My salary is well enough according to } \\
\text { my work hours }\end{array}$ & 3.06 & 61.2 & 1.50 & 49.1 & Neutral & 3 \\
\hline $\begin{array}{l}\text { I am satisfied with my chances of } \\
\text { increasing salary }\end{array}$ & 3.03 & 60.6 & 1.49 & 49.1 & Neutral & 5 \\
\hline The work I do is appreciated & 3.64 & 72.8 & 1.07 & 29.5 & Agree & 1 \\
\hline $\begin{array}{l}\text { I think those who do well at work have } \\
\text { fair opportunities for promotion }\end{array}$ & 3.38 & 67.6 & 1.18 & 35.0 & Neutral & 2 \\
\hline $\begin{array}{l}\text { It is possible to get a quick promotion } \\
\text { in my work }\end{array}$ & 3.04 & 60.8 & 1.27 & 41.7 & Neutral & 4 \\
\hline
\end{tabular}

From the table we conclude that "Job satisfaction" (in general) is Moderate from the perspective of the sample since the mean of responses is 3.23 which mean that the degree of agreement is "Neutral", and the coefficient of variation is $32 \%$ which means that the degree of agreement is $68 \%$ which indicates that there is an agreement between the respondents.

Concerning the phrases, the degree of agreement is "Agree" concerning "The work I do is appreciated", since the mean is 3.64 and "Neutral" concerning "I think those who do well at work have fair opportunities for promotion", "My salary is well enough according to my work hours", "It is possible to get a quick promotion in my work", "I am satisfied with my chances of increasing salary" since the mean is $3.38,3.06,3.04,3.03$ respectively.

The following figure shows the importance of "Job satisfaction".

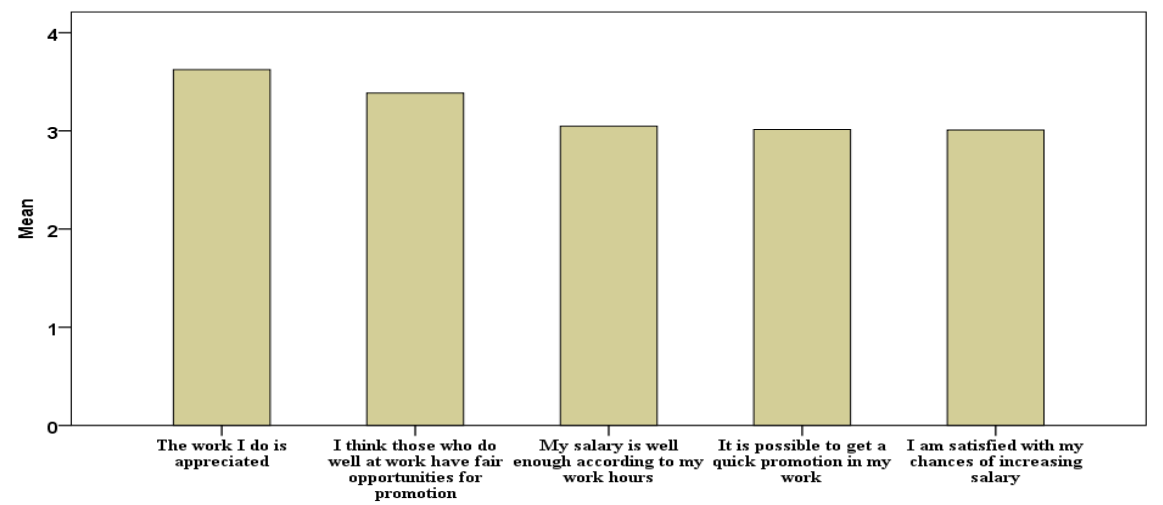

Figure (4): mean of sample responses concerning "Job satisfaction" 


\section{Turnover Intention}

To determine the importance of "Turnover intention" from the perspective of the sample, we conduct descriptive statistics (mean, relative mean, Standard deviation, coefficient of variation), and the results as follow:

Table (5): The descriptive statistics concerning "Turn over intention"

\begin{tabular}{lccrccc}
\hline \multicolumn{1}{c}{ Variables } & Mean & $\begin{array}{c}\text { Relative } \\
\text { mean }\end{array}$ & $\begin{array}{c}\text { Std. } \\
\text { Deviation }\end{array}$ & C.V & Agreement & Order \\
\hline $\begin{array}{l}\text { Turn over intention } \\
\text { I think a lot about leaving the } \\
\text { organization }\end{array}$ & 3.66 & 73.4 & 0.55 & 15.1 & Agree & \\
\hline $\begin{array}{l}\text { I am looking for an acceptable } \\
\text { alternative to this organization }\end{array}$ & 3.58 & 71.6 & 1.06 & 29.6 & Agree & 3 \\
$\begin{array}{l}\text { When I have the opportunity I will } \\
\text { leave work in this organization }\end{array}$ & 3.74 & 74.8 & 1.16 & 31.0 & Agree & 1 \\
\hline
\end{tabular}

From the table we conclude that "Turn over intention" (in general) is high from the perspective of the sample since the mean of responses is 3.67 which means that the degree of agreement is "Agree", and the coefficient of variation is $15.1 \%$ which means that the degree of agreement is $84.9 \%$ which indicates that there is an agreement between the respondents.

Concerning the phrases, the degree of agreement is "Agree" concerning "When I have the opportunity I will leave work in this organization", "I am looking for an acceptable alternative to this organization", "I think a lot about leaving the organization" since the mean is $3.74,3.69,3.58$ respectively.

The following figure shows the importance of "Turn over intention".

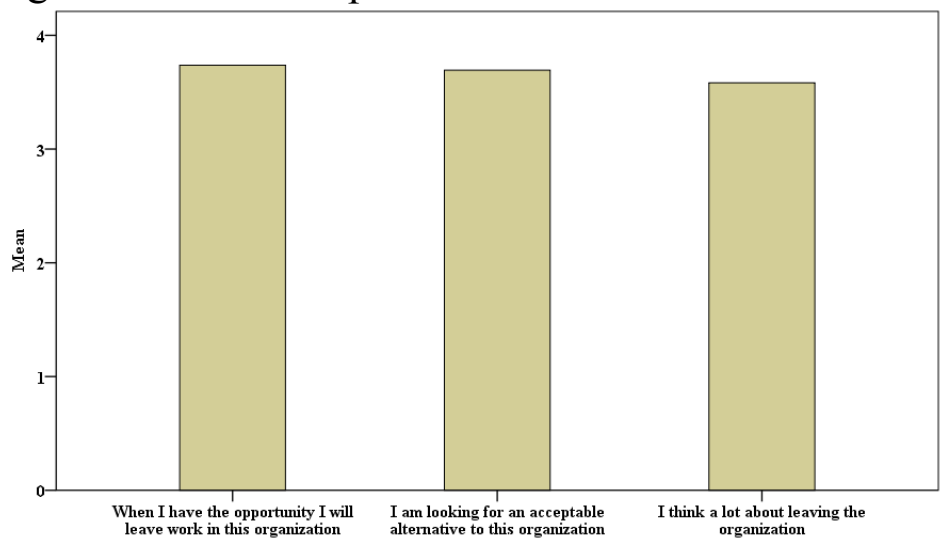

Figure (5): mean of sample responses concerning "Turn over intention" 


\section{Testing the $1^{\text {st }}$ null hypothesis}

Testing the research hypothesis H1 "There is no statistically significant relationship between person-organization (P-O) fit (value congruence, goal congruence) and job satisfaction (JS) in the private higher education in Egypt"

To test this hypothesis, a multiple regression analyses as follows:

\subsection{Multiple regression analysis}

The following table shows multiple regression analysis between "Values",

"Goals" as independent variables, "Job satisfaction" as dependent:

Table (6): Multiple regression analyses between "Values", "Goals" as independent variables, "Job satisfaction" as dependent variables

\begin{tabular}{|c|c|c|c|c|c|c|c|}
\hline \multicolumn{8}{|c|}{ Dependent Variable: Job satisfaction } \\
\hline \multirow{2}{*}{$\begin{array}{c}\text { Independent } \\
\text { Variables }\end{array}$} & \multirow[b]{2}{*}{ Coefficients } & \multicolumn{2}{|c|}{ T test } & \multirow{2}{*}{$\underset{\mathbf{R}}{\text { Multiple }}$} & \multirow[b]{2}{*}{$\mathbf{R}^{2}$} & \multicolumn{2}{|c|}{ F test } \\
\hline & & $\mathbf{T}$ & P-Value & & & $\mathbf{F}$ & P-Value \\
\hline Constant & $\alpha=0.756$ & 5.8 & 0.000 & & & & \\
\hline Values & $\beta 1=0.535$ & 14.1 & 0.000 & 0.778 & 0.605 & 285.5 & 0.000 \\
\hline Goals & $\beta 2=0.218$ & 4.3 & 0.000 & & & & \\
\hline
\end{tabular}

From the table we conclude that:

Testing the significant of the model ( $F$ test)

The model is significant since $(F=285.5, P$-value $<0.01)$ which means that there is a significant effect of "Values", "Goals" as independent variables on "Job satisfaction" as dependent variable.

After estimating the parameters of the regression model we can formulate the regression equation as the following:

Job satisfaction $=0.756+0.535 *$ Values $+0.218 *$ Goals $+\varepsilon$

Where: $\varepsilon$ random error

From the equation we conclude that:

- The minimum value of "Job satisfaction" is 0.756 (constant) which the value when "Values" and "Goals" = zero.

- There is a positive relationship between "Values" and "Job satisfaction" since $(\beta 1=0.535)$ which indicates the strength or degree of influence, means that when "Values" increases by (1 degree), it will follow by improving the rate of "Job satisfaction" by (0.535) degree. 
- There is a positive relationship between "Goals" and "Job satisfaction" since $(\beta 2=0.218)$ which indicates the strength or degree of influence, means that when "Goals" increases by (1 degree), it will follow by improving the rate of "Job satisfaction" by $(0.218)$ degree.

Testing the significant of the dependent variable ( $\mathrm{T}$ test)

It is clear from the $T$ test that $(T=14.1, P$-Value $<0.001)$ for "Values" and $(T=4.3$, $P$-Value $<0.001)$ for the "Goals" which confirms that the independent variables are significant at 0.01 level.

The explanatory power of the model (R square)

The value of $\left(R^{2}=0.605\right)$ which means that $(60.5 \%)$ from the changes at "Job Satisfaction" explained by "Values" and "Goals", which indicate that it is a moderate explanatory power.

From the previous we can reject the $1^{\text {st }}$ null hypothesis.

\section{Testing the $2^{\text {nd }}$ null hypothesis}

Testing H2 "There is no statistically significant relationship between personorganization (P-O) fit (value congruence, goal congruence) and turnover intention (TI) in the private higher education in Egypt".

To test this hypothesis, we conduct multiple regression analyses as follows:

Multiple regression analysis

The following table shows multiple regression analysis between "Values", "Goals" as independent variables, "Turnover Intention" as dependent:

Table (7): Multiple regression analyses between "Values", "Goals" as independent variables, "Turnover intention" as dependent variables

\begin{tabular}{|c|c|c|c|c|c|c|c|}
\hline \multicolumn{8}{|c|}{ Dependent Variable: Turnover intention } \\
\hline \multirow{2}{*}{$\begin{array}{c}\text { Independent } \\
\text { Variables }\end{array}$} & \multirow{2}{*}{ Coefficients } & \multicolumn{2}{|c|}{ T test } & \multirow{2}{*}{$\begin{array}{c}\text { Multiple } \\
\text { R }\end{array}$} & \multirow{2}{*}{$\mathbf{R}^{2}$} & \multicolumn{2}{|c|}{ F test } \\
\hline & & $\mathbf{T}$ & P-Value & & & $\mathbf{F}$ & P-Value \\
\hline Constant & $\alpha=4.862$ & 69.396 & 0.000 & & & & \\
\hline Values & $\beta 1=-0.135$ & -6.312 & 0.000 & 0.730 & 0.533 & 212.04 & 0.000 \\
\hline Goals & $\beta 2=-0.293$ & -9.910 & 0.000 & & & & \\
\hline
\end{tabular}

From the table we conclude that: 
Testing the significant of the model ( $\mathrm{F}$ test)

The model is significant since $(F=212.04, P$-value $<0.01)$ which means that there is a significant effect of "Values", "Goals" as independent variables on "Turn over intention" as dependent variable.

After estimating the parameters of the regression model we can formulate the regression equation as the following:

Turn over intention $=4.862-0.135 *$ Values $-0.293 *$ Goals $+\varepsilon$

Where: random error From the equation we conclude that:

- The minimum value of "Turn over intention" is 4.862 (constant) which the value when "Values" and "Goals" = zero.

- There is a negative relationship between "Values" and "Turn over intention" since $(\beta 1=-0.135)$ which indicates the strength or degree of influence, means that when "Values" increases by (1 degree), it will follow by decreasing the rate of "Turn over intention" by (-0.135) degree.

- There is a negative relationship between "Goals" and "Turn over intention" since $(\beta 2=-0.293)$ which indicates the strength or degree of influence, means that when "Goals" increases by (1 degree), it will follow by decreasing the rate of "Turn over intention" by (-0.293) degree.

Testing the significant of the dependent variable ( $\mathrm{T}$ test)

It is clear from the $T$ test that $(T=-6.312, P$-Value $<0.05)$ for "Values" and $(T=$ 9.910, P-Value $<0.01)$ for the "Goals" which confirms that the independent variables are significant at 0.01 level.

The explanatory power of the model (R square)

The value of $\left(R^{2}=0.533\right)$ which means that $(53.3 \%)$ from the changes at "Turnover intention" explained by "Values" and "Goals", which indicate that it is moderate explanatory power. From the previous we can reject the $2^{\text {nd }}$ null hypothesis. 


\section{Testing the $3^{\text {rd }}$ null hypothesis}

Testing H3: "There is no statistically significant relationship between job satisfaction (JS) and turnover intention (TI) in the private higher education in Egypt".

To test this hypothesis, simple regression analysis has been conducted. The following table shows multiple regression analysis between "Job satisfaction", as independent variable and "Turnover Intention" as dependent variable:

Table (8): Simple regression analyses between "Job satisfaction" as independent variables, "Turnover intention" as dependent variables

\begin{tabular}{|c|c|c|c|c|c|c|}
\hline \multicolumn{7}{|c|}{$\begin{array}{l}\text { Dependent Variable: Turnover intention } \\
\text { Independent Variable: Job satisfaction }\end{array}$} \\
\hline \multirow[b]{2}{*}{$\mathbf{R}$} & \multirow[b]{2}{*}{$\mathbf{R}^{2}$} & \multicolumn{2}{|c|}{ F test } & \multirow[b]{2}{*}{ Coefficients } & \multicolumn{2}{|c|}{ T test } \\
\hline & & $\mathbf{F}$ & P-Value & & $\mathbf{T}$ & P-Value \\
\hline \multirow{2}{*}{-0.539} & \multirow{2}{*}{0.290} & \multirow{2}{*}{152.7} & \multirow{2}{*}{0.000} & $\alpha($ Constant $)=4.57$ & 59.6 & 0.000 \\
\hline & & & & $\beta=-0.279$ & -12.4 & 0.000 \\
\hline
\end{tabular}

From the table we conclude that:

- There is a significant negative relationship between "Job satisfaction" and "Turnover intention" where the value of the correlation coefficient $(r=-0.539$, $P$-value $<0.01$, which means that "Job satisfaction" negatively affect "Turnover intention".

- After estimating the parameters of the regression model we can formulate the regression equation as the following:

Turnover Intention $=4.57-0.279 *$ Job satisfaction $+\varepsilon$

Where $\varepsilon$ : random error

Testing the significant of the model (F test)

The model is significant since $(F=20.870$, P-value $<0.001)$ which means that there is a significant effect of the Information system integration on the Interorganizational cost management.

Testing the significant of the dependent variable ( $\mathrm{T}$ test)

It is clear from the $T$ test for independent variable that $(T=-12.4, P$-Value $<0.01)$, which confirms that the independent variable is significant at 0.01 level. The value of ( $\beta=-0.279)$, which indicates the strength or degree of influence, means 
that when "Job satisfaction" improves by (1 degree), it will follow by decreasing the rate of Turnover intention by ( -0.279 degree). The explanatory power of the model (R square)

The value of $\left(R^{2}=0.29\right)$ which means that $(29 \%)$ from the changes at "Turnover intention" explained by "Job satisfaction", which indicate that it is a moderate explanatory power.

From the previous we can reject the $3^{\text {rd }}$ null hypothesis.

\subsection{The Research Model: Path Analysis}

To test the $4^{\text {th }}$ hypothesis "Job satisfaction (JS) has a mediating effect on the relationship between Person-organization (P-O) fit and turnover intention in the private higher education in sector Egypt", the researcher conducted "Structural Equation Modeling" (SEM) especially "Path Analysis" for its relevancy to the nature of the study model, since some variable "Job satisfaction" is independent and dependent at the same time (meditator variable). Figure 6 illustrates the realized results.

The following figure (6) illustrates the path analysis model, which includes the following variables:

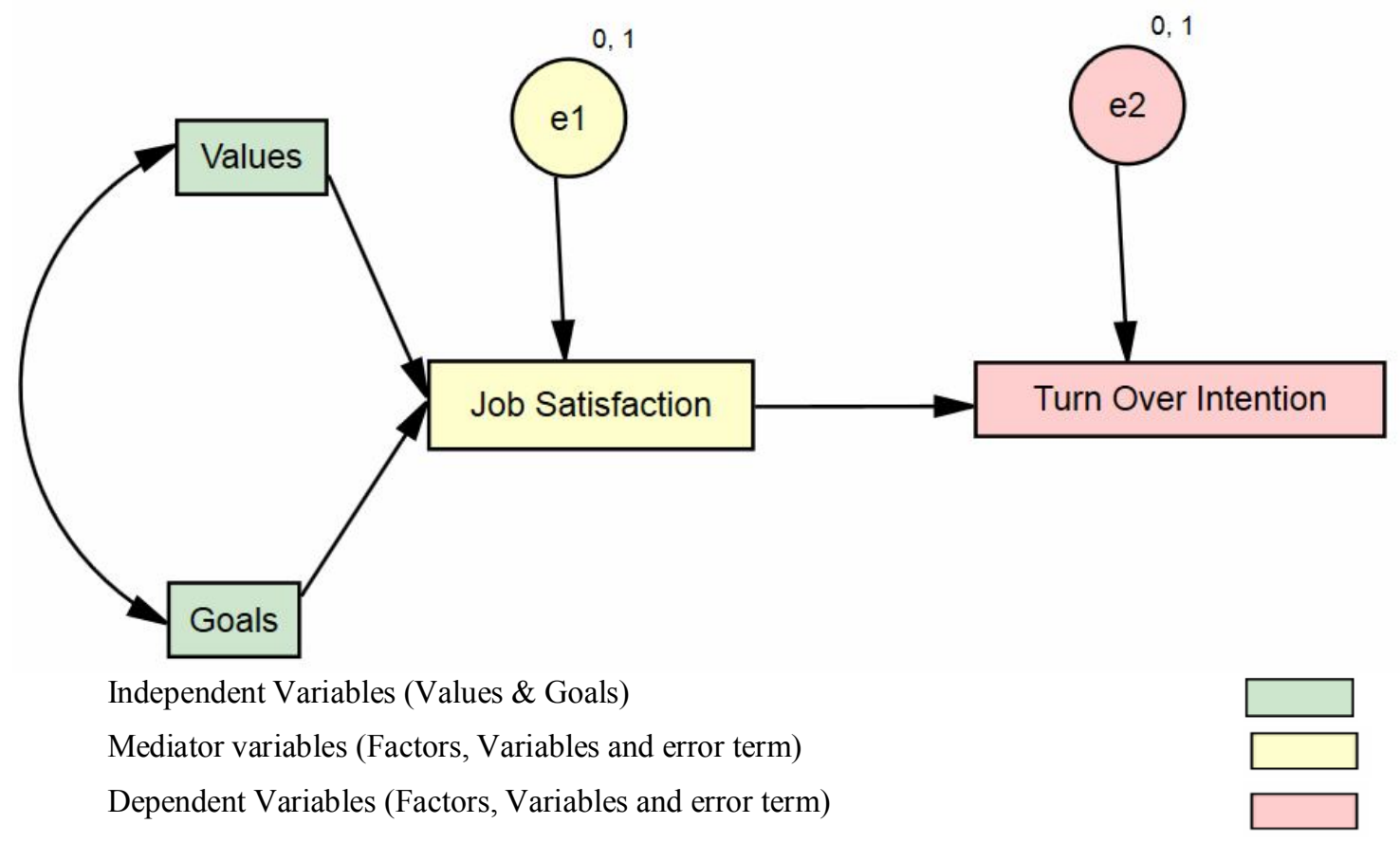

Figure (6): The suggested path analysis model Based on figure (6) the results can be summarized as follows: 
- The Variable "Turnover intention" is a dependent variable for the independent variables (Job Satisfaction, Goals, values).

- The variables "Job satisfaction" is a mediator variable since it is a dependent variable for the independent variables (Values, Goals) and it is considered an independent variable for the variable "Turn over intention".

- The variables (Values, Goals) are considered as independent variables.

- The double head arrows between independent variables measure the covariance between each pair of these variables.

- The one head arrows between the independent variables and mediator variable measure the variance in the mediator variable that explained by the independent variables.

- The one head arrows between the independent variables and dependent variable measure the variance in the dependent variable that explained by the independent variables.

- The unobserved variables (e1, e2) are considered the error terms that associated with the dependent variables.

\section{Testing Goodness of fit}

To test the goodness of fit of the suggested model which we obtained from the path analysis with the data of the questionnaire according to the standard tests we obtained the following table:

Table (9): Goodness of fit indices

\begin{tabular}{lcl}
\hline \multicolumn{1}{c}{ Indicator } & Value & $\begin{array}{l}\text { Suggested } \\
\text { Guidelines }\end{array}$ \\
\hline CMIN/DF (Chi Square/df) & $1.414 \leq 3$ \\
\hline GFI (Goodness of Fit Index) & $0.998 \geq 0.9$ \\
\hline CFI (Comparative Fit Index) & $0.999 \geq 0.9$ \\
\hline TLI (Tucker- Lewis Index) & $0.996 \geq 0.9$ \\
\hline RMSEA Root Mean Square Error of Approximation & $0.033 \leq 0.08$ \\
\hline
\end{tabular}


After studying and analyzing the relationships in the figure (6), it is clear from the goodness of fit indices that the model good fit with the sample data, for the following reasons:

$\mathrm{CMIN} / \mathrm{DF}=1.414<3$,

RMSEA $=>0.033$

All other indices (GFI, CFI and TLI) are acceptable since their values are $>0.9$, so the model is good, it does fit the sample data.

According to the previous figure no. (6), the researcher specified (the estimated regression weights).

Table (10): the estimated regression weight for the model

\begin{tabular}{lccccc}
\hline & Variables & Estimate & $\begin{array}{c}\text { Standard } \\
\text { Error }\end{array}$ & $\begin{array}{c}\text { Critical } \\
\text { Value }\end{array}$ & Sig. \\
\hline $\mathrm{X} 3<--$ & $\mathrm{X} 2$ & .218 & .051 & 4.294 & $* * *$ \\
\hline $\mathrm{X} 3<--$ & $\mathrm{X} 1$ & .535 & .038 & 14.148 & $* * *$ \\
$\mathrm{X} 3<---$ & $\mathrm{e} 1$ & .648 & .024 & 27.386 & $* * *$ \\
\hline $\mathrm{X} 4<---$ & $\mathrm{e} 2$ & .449 & .016 & 27.350 & $* * *$ \\
\hline $\mathrm{X} 4<---$ & $\mathrm{X} 3$ & -.279 & .022 & -12.408 & $* * *$ \\
\hline & & Intercept & & & \\
\hline $\mathrm{X} 3$ & & .756 & .129 & 5.852 & $* * *$ \\
\hline $\mathrm{X} 4$ & 4.568 & .076 & 59.875 & $* * *$ \\
\hline
\end{tabular}

where $\mathrm{X}_{1}$ "Values", $\mathrm{X}_{2}$ "Goals", $\mathrm{X}_{3}$ "Job satisfaction", $\mathrm{X}_{4}$ "Turn over intention", e1, e2 "Error terms".

From the table we conclude that:

- There is a positive significant relationship between X1 "Values", X2 "Goals" as independent variables and X3 "Job satisfaction" as dependent variable, and the equation is as follow:

$X 3=0.756+0.535 * X 1+0.218 * X 2+e 1$ (equation 1)

Where $X_{1}$ "Values", X2 "Goals", $X_{3}$ "Job satisfaction", e1 "error" for equation 1.

- There is a negative significant relationship between X3 "Job satisfaction" as independent variable and X4 "Turnover intention" as a dependent variable.

$X 4=4.568-0.279 * X 3+e 2$ (equation 2)

Where X3"Job satisfaction", $\mathrm{X}_{4}$ "Turnover intention", e2 "error" for equation 2. From equations $(1,2)$ we conclude that X3 "Job satisfaction" is a mediator variable since it is a dependent variable in the $1^{\text {st }}$ relation, and an independent 
variable in the $2^{\text {nd }}$ relation, so we accept the $4^{\text {th }}$ hypothesis "H4: Job satisfaction (JS) has a mediating effect on the relationship between Person-organization (P-O) fit and turnover intention in the private higher education in Egypt.

Direct, indirect and total effect

The following table illustrates the direct, indirect and total effect of independent variables, intermediate variable on dependent variable:

Table (11): The direct, indirect and total effect of independent variables, intermediate variable on dependent variable

\begin{tabular}{lllcc}
\hline \multicolumn{1}{c}{ Variables } & \multicolumn{1}{c}{ Effect } & $\begin{array}{c}\text { X1 } \\
\text { Values }\end{array}$ & $\begin{array}{c}\text { X2 } \\
\text { Goals }\end{array}$ & $\begin{array}{c}\text { X3 } \\
\text { Job satisfaction }\end{array}$ \\
\hline \multirow{2}{*}{ X3 } & Direct & 0.535 & 0.218 & \\
Job satisfaction & Indirect & 0.000 & 0.000 & \\
& Total & 0.535 & 0.218 & \\
\hline \multirow{2}{*}{ X4 } & Direct & 0.000 & 0.000 & -0.279 \\
Turnover intention & Indirect & -0.149 & -0.061 & 0.000 \\
& Total & -0.149 & -0.061 & -0.279 \\
\hline
\end{tabular}

From the table we conclude that:

- The Variable $\mathrm{X}_{1}$ "Values" has a direct positive effect on $\mathrm{X}_{3}$ "Job satisfaction" $=0.535$, and X3 "Job satisfaction" has a direct negative effect on $\mathrm{X}_{4}$ "Turnover intention" = 0.279 , So the indirect negative effect of $\mathrm{X}_{1}$ "Values" on $\mathrm{X}_{4}$ "Turnover intention" = $0.535 *-0.279=-0.149$ as showing from the figure:

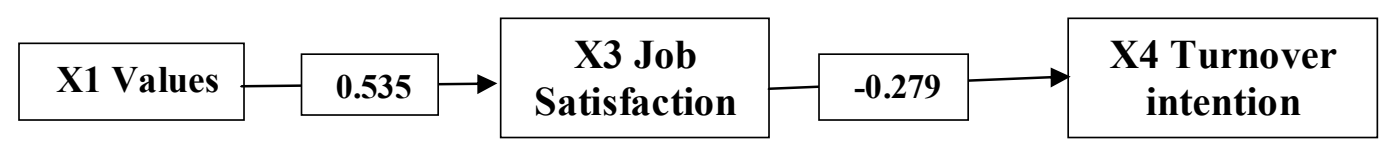

- The Variable X2 "Goals" has a direct positive effect on X3 "Job satisfaction" $=0.218$, and $\mathrm{X}_{3}$ "Job satisfaction" has a direct negative effect on $\mathrm{X}_{4}$ "Turnover intention" = 0.279 , So the indirect negative effect of $\mathrm{X}_{1}$ "Values" on $\mathrm{X}_{4}$ "Turnover intention" = $0.218^{*}-0.279=-0.061$ as showing from the figure:

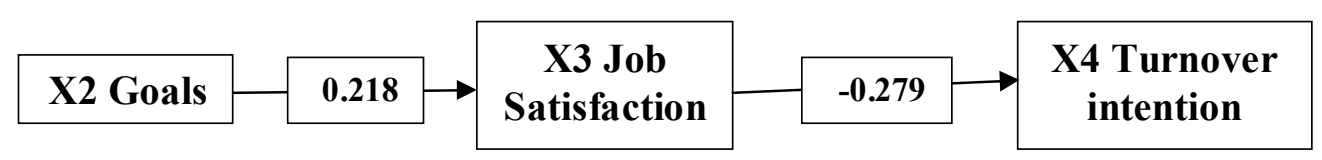


- From testing the $\mathrm{H}_{2}$ the effect of $\mathrm{X}_{1}$ "Values" on $\mathrm{X}_{4}$ "Turnover intention" without the meditation of $\mathrm{X}_{3}$ "Job satisfaction" was -.0.135, while with meditation from testing $\mathrm{H}_{4}$ was -0.149 , so Job satisfaction has a meditating effect between values and turnover intention.

- From testing the $\mathrm{H}_{2}$ the effect of $\mathrm{X}_{2}$ "Goals" on $\mathrm{X}_{4}$ "Turnover intention" without the meditation of $\mathrm{X}_{3}$ "Job satisfaction" was -.0.239, while with meditation from testing $\mathrm{H}_{4}$ was -0.061 , so Job satisfaction has no meditating effect between Goals and turnover intention.

From the previous we accept partially $\mathrm{H}_{4}$ "Job satisfaction (JS) has a mediating effect on the relationship between Person-organization (P-O) fit and turnover intention at private high institutes in Egypt.

\section{Discussion and Results}

The researcher adopted a complete census from the population of study (academic staff of October University) and after analyzing data, he obtained the following results:

- From reliability analysis the value of Cronbach's alpha is $(0.927,0.617,0.854$, 0.873) concerning the sections of the questionnaire respectively, which reflected on honesty coefficient and its value was $(0.963,0.785,0.924,0.934)$ respectively. This is mean that questionnaire is reliable, and we can depend on the results obtained from this questionnaire. The correlation coefficients between phrases and the sections belongs to, showed internal consistency.

- By describing the sections of the study we discovered that the level of "Values congruence", "Goal congruence" and "Job satisfaction" (in general) is moderate from the perspective of the sample, while the level of "Turnover intention" is high, which required great effort to reduce it.

- Accepted the null hypothesis H1 "There is no statistically significant relationship between person-organization (P-O) fit (value congruence, goal congruence) and job satisfaction (JS) in the private higher education in Egypt", since there were a significant relationship between personorganization (P-O) fit (value congruence, goal congruence) and job 
satisfaction (JS), and we conduct multiple regression analysis and estimated the regression equation:

Job satisfaction $=0.756+0.535 *$ Values $+0.218 *$ Goals $+\varepsilon$

Where: $\varepsilon$ : Random error. We tested the significant of the model and $R$ square $=60.5 \%$.

- Accepted the second null hypothesis $\mathrm{H}_{2}$ "There is no statistically significant relationship between person-organization (P-O) fit (value congruence, goal congruence) and turnover intention (TI) in the private higher education in Egypt", since there were a significant relationship between personorganization (P-O) fit (value congruence, goal congruence) and turnover intention (TI), and we conduct multiple regression analysis and estimated the regression equation:

Turn over intention $=4.862-0.135 *$ Values $-0.293 *$ Goals $+\varepsilon$

Where: $\varepsilon$ : Random error. We tested the significant of the model and $R$ square $=53.3 \%$.

- Accepted the third null hypothesis $\mathrm{H}_{3}$ "There is no statistically significant relationship between job satisfaction (JS) and turnover intention (TI) in the private higher education sector in Egypt", since there were a significant relationship between job satisfaction (JS) and turnover intention (TI), and we conduct multiple regression analysis and estimated the regression equation:

- Turnover Intention $=4.57-0.279 *$ Job satisfaction $+\varepsilon$

- Where: $\varepsilon$ : Random error. We tested the significant of the model and $R$ square $=29 \%$.

- Accept the fourth null hypothesis "Job satisfaction (JS) has a mediating effect on the relationship between Person-organization (P-O) fit and turnover intention in the private higher education sector in Egypt" by conducting path analysis, and we obtained the following results:

- The variables $\mathrm{X}_{1}$ "Values" $\mathrm{X}_{2}$ "Goals" has positive direct effect on "Job satisfaction", since the values of effect are $0.535,0.218$ respectively. 
- The variables $\mathrm{X}_{1}$ "Values" $\mathrm{X}_{2}$ "Goals" has negative indirect effect on "Turnover intention", since the values of effect are $-0.149,-0.061$ respectively.

- The variable $\mathrm{X}_{3}$ "Job satisfaction" has negative indirect effect on "Turnover intention", since the value of effect is -0.279 .

\section{Recommendations}

Higher education institutions depend on their employees' skills, knowledge and abilities for these institutions It is thus necessary for organizations to consider the relationship between (P-O) fit, job satisfaction and turnover intention in the formulation of their retention strategies

This research provides a new insight into understanding the integration between the P-O fit, job satisfaction and turnover intention . In doing so, this research contributes to the $\mathrm{P}-\mathrm{O}$ fit, job satisfaction and turnover initiation literature by proposing a mediating empirical model to better explain the causal ties among the constructs..

In light of the results of the field study, the researcher recommends the following:

- Since "Turnover intention" is negatively affected by the "Values congruence", the "Values congruence" could be improved through different procedures such as:

a) It is necessary to determine the values and culture of the organization in cooperation with faculty members.

b) It is necessary to match the values and culture of the organization with the values from the perception of faculty members.

- Since "Turnover intention" is negatively affected by the "Goals congruence", the "Goals congruence" may be improved through these procedures.

- It is necessary to clarify the goals of the Organization, and to develop executable strategic plans, with a timetable for their achievement.

- Motivate the teaching staff to accomplish the goals of the organization. 
- Since "Turnover intention" is negatively affected by the "Job satisfaction" , "job satisfaction" could be improved through these procedures":

- The salary of faculty members must fit their efforts, and improve the chances of increasing salary to match the inflation of living.

- Setting precise and clear KPI (key Performance Indicators) for measuring performance and specify the promotion opportunities according to these indicators.

- Improve work environments which would allow staff to develop their selfconfidence, motivation, and relationship with each other.

This research proposed that future research could empirically examine the proposed model by testing it in different areas, sectors and regions. Moreover, future studies may include other behavioral constructs, to extend and verify the proposed framework. 


\section{References}

- Alle, N.J., and Meyer, J.P.(1996). Affective, Continuance, and Normative Commitment to the Organization: An Examination of Construct Validity, Journal of Vocational Behavior, 49(3), 252-276.

- Arthur, W. Jr., Bell, S. T., Villado, A. J., \&Doverspike, D. (2006). The use of personorganization fit in employment decision making: An assessment of its criterionrelated validity. J ApplPsychol, 91(4), 786-801.

- Aryee, S., Wyatt, T., and Min, M.K.(2001). Antecedents of Organizational Commitment and Turnover Intentions among Professional Accountants in Different Employment Setting in Singapore, Journal of Social Psychology, 131(4), 545-556.

- Aydogdu ,S., and Asikgil,B.(2011). An Empirical Study of The relationship among Job Satisfaction, Organizational Commitment, and Turnover Intention, International Review of Management and Marketing, 1(3), 43-53.

- Biswas, S., \& Bhatnagar, J. (2013). Mediator analysis of employee engagement: Role of perceived organizational support, P-O Fit, Organizational Commitment and Job Satisfaction. Research, 38(1), 27-40.

- Boswell, W. R., Ren, L. R., \&Hinrichs, A. T. (Eds.). (2008). Voluntary Employee Turnover: Determinants, Processes, and Future Directions (Vol. I). London: SAGE Publications.

- Cable,\& Judge. (1996). Person-Organization Fit, Job Choice Decisions, and Organizational Entry. Organizational Behavior and Human Decision Processes, 67(3), 294-311.

- Cable, D. M., \&DeRue, D. S. (2002). The convergent and discriminant validity of subjective fit perceptions. Journal of Applied Psychology, 87, 875-884 .

- Chan ,E.Y., and Morrison, P. (2000) . Factors Influencing The Retention and Turnover Intentions of Registered Nurses in a Singapore Hospital, Nursing and Health Sciences, 2(1), 113-121.

- Chatman, J. (1989). Improving interactional organizational research: A model of person- organization fit. Academy of Management Review, 14, 333-349.

- Chatman, J. A. (1991). Matching People and Organizations: Selection and Socialization in Public Accounting Firms. Administrative Science Quarterly, 36(3), 459-483. 
- Chen ,P.Y., and Spector P.E.(1991). Negative Affectivity as The Underlying Cause of Correlations between Stressors and Strains, Journal of Applied Psychology, 76(3), 398-407.

- Cramer, D.(1996).Job satisfaction and Organizational Continuance Commitment: A Two-Wave Panel Study, Journal of Organizational Behavior, 17, 389-400.

- De Moura, G.R . ,Abrams, D., Retter, C., Gunnarsdottir, S., and Ando,K. (2009).Identification as an Organizational Anchor: How Identification and Job Satisfaction Combine to Predict Turnover Intention. European Journal of Social Psychology, 39(4), 540-557.

- Elfenbein, H. A., \& O'Reilly, C. A. (2007). Fitting in: The effects of relational demography and person-culture fit on group process and performance. Group and Organization Management, 32(1), 109-142 .

- Ferris ,K.R., and Aranya,N.(1983). A Comparison of Two Organizational Commitment Scale, Personnel Psychology, 36(1), 87-98.

- Gatsonis, C. and Sampson, A.R. (1989), "Multiple Correlation: Exact Power and Sample Size Calculations," Psychological Bulletin, 106, 516-524.

- Hackman, J.R. and Oldham, G.R. (1975), "Development of the job diagnostic survey”, Journal of Applied Psychology, Vol. 60, pp. 159-70.

- Hendrix, W., Robbins, T., Miller, J., T. Summers, 1998. Effects of Procedural and Distributive .

- Hoffman, B. J., \&Woehr, D. J. (2006). A quantitative review of the relationship between person-organization fit and behavioral outcomes. Journal of Vocational Behaviour, 68(3), 389-399. http://dx.doi.org/10.1016/j.jvb.2005.08.003

- Hoffman, B. J., \&Woehr, D. J. (2006). A quantitative review of the relationship between person-organization fit and behavioral outcomes. Journal of Vocational Behavior, 68(3), 389-399. http://dx.doi.org/10.1016 /j.jvb.2005.08.003.

- Holtom, B. C., Mitchell, T., Lee, T., \& Inderrieden, E. (2005). Shocks as causes of turnover: Why they are and how organizations can manage them. Human Resource Management, 44, 337-352.

- Huber, G. P. (1991). Organizational learning: The contributing processes and the literatures. Organization Science(Special Issue: Organizational Learning: Paper in Honor of (and by) James G.), 88-115. 
- Huselid, M. A., Jackson, S. E., \& Schuler, R. S. (1997). Technical and strategic human resource management effectiveness as determinants of firm performance. Academy of Management Journal, 40(1), 171-188.

- Jaros, S. J. (1997). An Assessment of Meyer and Allen's 1991 Three-Component Model of Organization Commitment and Turnover Intentions. Journal of Vocational Behavior, 51, 319-337.

- Jaros, S.J., Jermier,J.M ., Koehler, J.W., and . Sincich,T.(1993). Effects of Continuance, Affective, and Moral Commitment on The Withdrawal Process: An Evaluation of Eight Structural Equation Models, Academy of Management Journal, 36(5), 951-995.

- Johnson, A. (1995). The business case for work-family programs. Journal of Accountancy, 180(2), 53-59.

- Juhdi, N., Pa'wan, F., \&Hansaram, R. M. K,(2013). HR Practices and Turnover intention: The mediating roles of organizational commitment and organizational engagement in a selected region in Malaysia. The International Journal of Human Resource Management, 24(15), 3002-3019.

- Jung, H. S., \& Yoon, H. H. (2013). The effects of organizational service orientation on person-organization fit and turnover intent. The Service Industries Journal, 33(1), 7-29.

- Kim, T.-Y., Aryee, S., Loi, R., \& Kim, S.-P. (2013). Person-organization fit and employee outcomes: test of a social exchange model. The International Journal of Human Resource Management, 24(19), 3719-3737. doi: 10.1080/09585192.2013.781522.

- Kristof-Brown, A. I. (1996). Person-organization fit: An integrative review of its conceptualizations, measurement and implication. Personnel Psychology, 49(1), 1-49.

- Kristof-Brown, A. L., Zimmerman, R. D., \& Johnson, E. C. (2005). Consequences of individuals' fit at work: A meta analysis of person-job person-organizaton, persongroup and person-supervisor fit. Personnel Psychology, 58, 281-342.

- Maxwell K. Hsu, James J. Jiangb, Gary Kleinc\&ZaiyoungTangd,(2003). Perceived career incentives and intent to leave, Information \& Management. 361-369.

- Mobley W. H., Griffeth R., Hand, H. and B. Meglino, (1979). A Review and Conceptual Analysis of the Employee Turnover Process, Psychological Bulletin 86, 493-522. 
- Muliawan, A.D., Green, P.F., and D. A. Robb, 2009. The Turnover Intentions of Information Systems Auditors. International Journal of Accounting Information Systems, 10(3), 117- 136.

- Mwadiani M, Akpotu N. E. (2002). Academic Staff Turnover in Nigerian Universities: Education Journal, Vol.123

- Naris, N.S., \&Ukpere, I.W. (2010). Developing a retention strategy for qualified staff at the Polytechnic of Namibia. African Journal of Business Management, 4(6), $1078-1084$.

- Netemeyer, R.G., Burton, S.,and Johnston, M.W.(1995). A Nested Comparison of Four Models of the Consequences of Role Perception Variables, Organizational Behavior and Human Decision Process, 61(1), 77-98.

- Ng'ethe, J. M, Iravo, M. E, \& Namusonge, G. (2012). Determinants of Academic Staff Retention in Public Universities in Kenya: Empirical Review. International Journal of Humanities and Social Science, 2 (13), 205-213.

- Parkes, L.P., Boncher, S., Schneider, S.K. (2001). Person-organization fit across cultures: An empirical investigation of individualism and collectivism. Applied Psychology: An International Review, 50(1), 81-108.

- Price ,J .L., and Mueller,C.W.(1981). A Causal Model of Turnover for Nurse, Academy of Management Journal, 24(3),543-565

- Rainey, H. G. (2003). Understanding and Managing Public Organizations, (3rd ed.). San Francisco, CA: Jossey-Bass.

- Reilly,C.O., and Chatman, J.(1986) . Organizational Commitment and Psychological Attachment: The Effects of Compliance, Identification, and Internalization on Prosocial Behavior, Journal of Applied Psychology, 71(3), 492-499.

- Resick, C. J., Baltes, B. B., \& Shantz, C. W. (2007). Person-organization fit and work-related attitudes and decisions: Examining interactive effects with job fit an conscientiousness. Journal of Applied Psychology, 92, 1446-1455

- Roodt, G. (2004). Turnover intentions. Unpublished document. Johannesburg: University of Johannesburg.

- Schneider, B. (1987). The people make the place. Personnel Psychology, 40, 437-454.

- Sekiguchi, T. (2004), Person-organization fit and person-job fit in employee selection: A review of the literature. Osaka KeidaiRonshu, 54(6), 179-196. 
- Sousa-Poza, A. and F. Henneberger,( 2002). Analyzing Job Mobility with Job Turnover.

- Sousa-Poza, A., 2007. The Effect of Job Satisfaction on Labor Turnover by Gender: An Analysis for Switzerland. The Journal of Socio-Economics 36, 895-913.

- Spector, P.E. (1997). Job Satisfaction: Application, Assessment, Causes, and Consequences, Sage, Thousand Oaks, CA.

- Steensma, H., Van Breukelen, W., and M. Sturm, (2004). Studying Employee Turnover by Splitting up the usual Comparison Group. Journal of Individual Employment Rights, 11, 211-227.

- Takase, M. (2001). A concept analysis of turnover intention: Implications for nursing management, Collegian, Vol.17, pp.3-12.

- Tett, R.P. and Meyer, J.P. (1993). Job satisfaction, organizational commitment, turnover intention, and turnover: Path analyses based on meta-analytic findings. Personnel Psychology, 462, 259-293.

- Van Vianen, A.E.M. (2000). Person-organization fit: The match between newcomers' and recruiters' preferences for organizational cultures. Personnel Psychology, 53, 113-149.

- Vandenberghe ,C.,and Tremblay, M.(2008). The Role of Pay satisfaction and Organizational Commitment in Turnover Intentions: A Two-sample Study, Journal of Business \& Psychology, 22(3), 275-286.

- Verquer, M.L., Beehr, T.A., Wagner, S.H. (2003), A meta-analysis of relations between person-organization fit and work attitudes. Journal of Vocational Behavior, $63,473-489$

- Vogel, R. M., \& Feldman, D. C. (2009). Integrating the levels of person-environment fit: The roles of vocational fit and group fit. Journal of Vocational Behavior, 75(1), 68-81.

- Westerman, J. W., \& Cyr, L. A. (2004b). An Integrative Analysis of PersonOrganization Fit Theories. International Journal of Selection and Assessment, 12(3), 252-261.

- Yuce,I.(2012). Examining The Relationship among Job Satisfaction, Organization Commitment, and Turnover Intention: An Empirical Study, International Journal of Business and Management, 7(20), 44-58. 